\title{
Fallopian Tube Cancer pT3c TNM Finding v7
}

National Cancer Institute

\section{Source}

National Cancer Institute. Fallopian Tube Cancer pT3c TNM Finding v7. NCI Thesaurus.

Code 689681.

Fallopian tube cancer with peritoneal metastasis outside the pelvis and more than $2 \mathrm{~cm}$ in diameter. (from AJCC 7th Ed.) 